\title{
Great global geotourism sites
}

To raise geology's global profile, Murray Gray presses the Society to support an international project on geotourism

n 2014, the Geological Society of London, together with partner organizations, ran a "100 Great Geosites" project in the UK and Ireland (https://www.geolsoc.org. uk/100geosites). Over 400 sites were nominated and the public were invited to vote for their favourites. 1,500 votes were received, with the 100 most popular being placed into 10 groups.

According to Professor Rob Butler, Chairman of the Geoconservation Committee, the project generated a "pretty major media storm" amounting to some of the largest ever media interest in a Geological Society topic. Given the low profile of geology, geoheritage and geoconservation in many countries, I believe there is a case for repeating the Great Geosites project at a global scale?

\section{Selection}

We would need to determine how many sites and what criteria to use in our selection. Certainly, the public must be able to easily and safely visit the locations, and we must consider visual impact, site quality, educational potential and the availability of sufficient tourist facilities. The sites should be globally distributed, rather than focussed on a single continent, and should reflect the geodiversity of the planet.

With these strictures in mind, I propose a number of sites for potential inclusion. For example, the Iguaçu Falls represent the world's most complex waterfall system, with 275 individual falls tumbling over two main horizontal lava flows. Most geosites are static, but this highly dynamic site has good tourist facilities, including trails over the water, helicopter and boat trips, visitor centres and restaurants.

The Great Barrier Reef may seem a surprising site to champion, given that most visitors are interested in the reef ecology rather than its geology. However, it is believed that the reef started to grow
20,000 years ago, when world sea-level was $120 \mathrm{~m}$ lower. As sea-levels rose, coral growth kept pace, creating the massive structure we see today.

There ought to be a karst site on the list, and South China Karst and Ha Long Bay together contain world-class examples of tower and cone karst, as well as giant dolines, river gorges, cave systems and the stone forest of Shilin.

The World's most impressive in situ dinosaur site must be the dinosaur footprint site at Parque Cretácico, Cal Orcko, near Surce, southern Bolivia. Here, over 5,000 footprints from 15 dinosaur species are preserved.

The Golden Circle tourist route in south-west Iceland includes Thingvellir, where the North American and European plates are moving apart at about $3 \mathrm{~cm}$ per year, resulting in open fissures, some of which have walking or canoe trails through them.

Finally, Cape Town and Rio de Janeiro both reflect the important and close association between human settlements and their physical settings.

\section{Debate}

These sites are not intended as a definitive list. Rather, I hope they will trigger discussion and start a process that may lead to a list of top geotourism sites endorsed by the geological community, which can then be promoted to the public through the media. Endorsement should come through national and international organisations such as the Geological Society of London, as well as the IUGS's International Commission on Geoheritage and the IUCN's Geoheritage Specialist Group.

Murray Gray (FGS) is Honorary Professor in the School of Geography at Queen Mary University of London; e-mail: j.m.gray@qmul.ac.uk. The full article, including more detailed justification for each proposed site, is available online

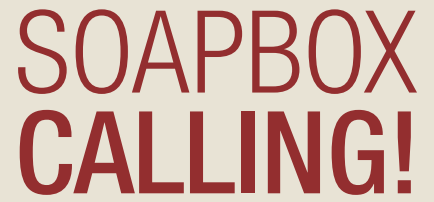

Soapbox is open to contributions from all Fellows. You can always write a letter to the Editor, of course, but perhaps you feel you need more space?

If you can write it entertainingly in 500 words, the Editor would like to hear from you. Email your piece, and a self-portrait, to amy.whitchurch@geolsoc.org. uk. Copy can only be accepted electronically. No diagrams, tables or other illustrations please.

Pictures should be of print quality - please take photographs on the largest setting on your camera, with a plain background.

Precedence will always be given to more topical contributions. Any one contributor may not appear more often than once per volume (once every 12 months).

GIVEN THE LOW
PROFILE OF
GEOLOGY, GEOHERITAGE
AND GEOCONSERVATION
IN MANY COUNTRIES,
PERHAPS THERE IS A
CASE FOR REPEATING
THE GREAT GEOSITES
PROJECT AT A GLOBAL
SCALE?

